\title{
A STRATEGIC ANALYSIS OF ALLEGRO: A CUSTOM MADE SUPPLY CHAIN MANAGEMENT SOFTWARE
}

\author{
Zulfany Erlisa Rasjid \\ Jurusan Teknik Informatika, Fakultas Ilmu Komputer, Bina Nusantara University \\ Jln. K.H Syahdan No 9, Palmerah, Jakarta Barat 11480 \\ zulfany@rad.net.id, Zulfany@binus.ac.id
}

\begin{abstract}
Allegro is a Supply Chain Management software which is used by one of the Buying Agent that has branches all over the world. Allegro is a tailor-made application specially build for the Buying Agent. Allegro thas a lot of capability, however it is not being used optimally. This paper analyszes the software such that it can be used optimally to support the company (Buying Agent) strategically and help the company to perform better by using Balance Score Card and KPI generated by the use of the system. The KPI is derived from the Business Objectives and the data in fact are all available in Allegro which is currently not used. As a conclusion, the writer suggested using all features available from Allegro and hence it will prove the overall performance of the company.
\end{abstract}

Keywords: KPI, balance score card, supply chain

\begin{abstract}
ABSTRAK
Allegro adalah sistim untuk Supply Chain Manaement yang digunakan oleh salah satu Agen Pembelian yang memiliki cabang di seluruh dunia. Allegro adalah sebuah aplikasi khusus dibuat berdasarkan kebutuhan perusahaan secara khusus. Allegro memiliki banyak kemampuan, namun belum digunakan secara optimal. Makalah ini menganalisa sistim Allegro sedemikian rupa sehingga dapat digunakan secara optimal untuk membantu perusahaan (Buying Agent) secara strategis dan membantu perusahaan untuk memperoleh kinerja yang lebih baik dengan menggunakan Balance Score Card dan KPI yang dihasilkan dari menggunakan system tersebut. KPI berasal dari Tujuan Bisnis dan sebenarnya, data telah tersedia di Allegro yang saat ini tidak digunakan. Sebagai kesimpulan, penulis menyarankan untuk menggunakan semua fitur yang tersedia pada Allegro dan diharapkan akan meningkatkan kinerja perusahaan secara keseluruhan.
\end{abstract}

Kata kunci: KPI, balance score card, supply chain 


\section{INTRODUCTION}

A Supply Chain Management software called Allegro is custom made for a Buying Agent where the head office is in Germany and has many agents and representative office all over the world. This Buying Agent chooses to tailor-made their Supply Chain Management Software because of the nature of their processes which is not quite the same with other Buying Agents. There is no problem with the software itself; however the writer feels that this software is not fully utilized. Basically, the software is only used to handle the basic operations starting from the supplier sourcing until the print of commission. In this paper I will analyse the software in its strategic view, and see how this software can be used to and enhancedover other aspects than just the basic operation and to see whether how to improve the software to become better and to be able to handle the Supply Chain Management in a more strategic situation and therefore benefit the user more. I will also analyze this software such that it can be linked to the Key Performance Indicator of the company and employees of this company.

The existing software is used maincly in the Merchandise Department, which is the heart of the operation. The buyer place oders through the Merchandise Department, where they liaise with the suppliers. It is the responsibility of the Merchandise Department to find the best supplier for an order. Once an order is placed, it will be followed up by the Quality Assurance and Shipping Department. The Merchandise department must nsure a punctual delivery of the items. The software handles this well. However, it is only the basic operation and yet, other modules exists in the software which is not used at all. This paper will analyze the software such that it can be used by the company to make decision strategically, such as shoosing the best supplier for an item and also allow to measure the company's KPI (Key Performance Indicator). The scope of the analysis covers the following area, as indicated in the following diagram:

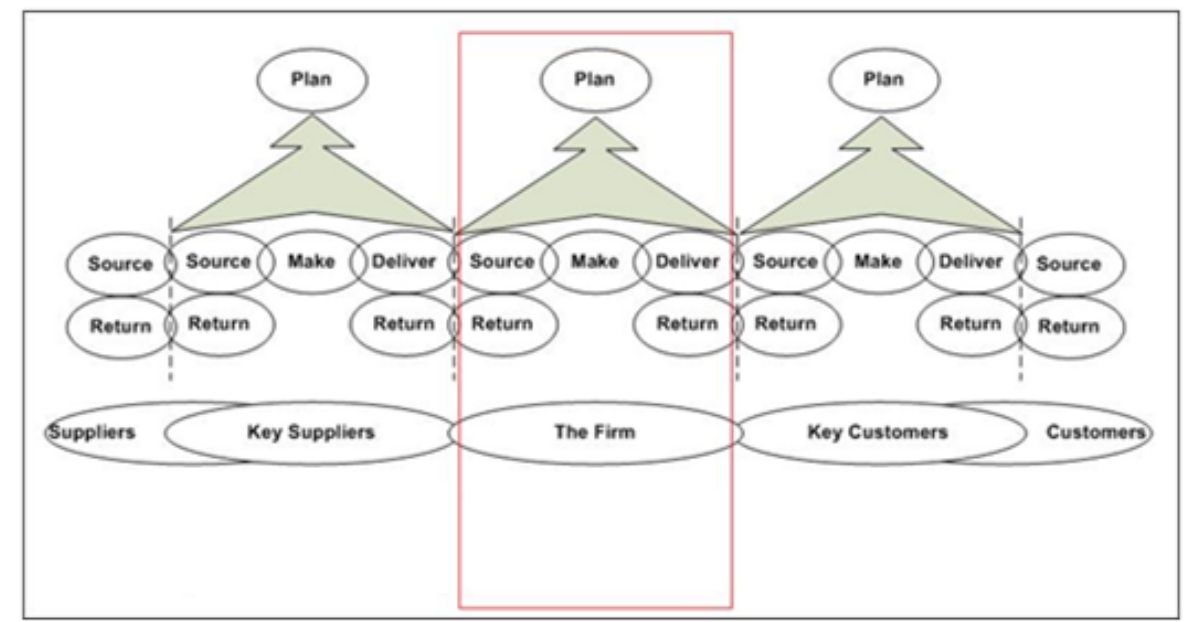

Figure 1 Study Coverage

\section{Supply Chain and Supply Chain Management}

In general, as stated by Chaffey \& Woods (2005), a supply chain covers the whole activities from sourcing until the delivery of goods to the customers. Romney \& Steinbart (2006) stated that Supply Chain is: A system that include the Value Chain of an organization and its supplier and distributors and customers (see Figure 2). 


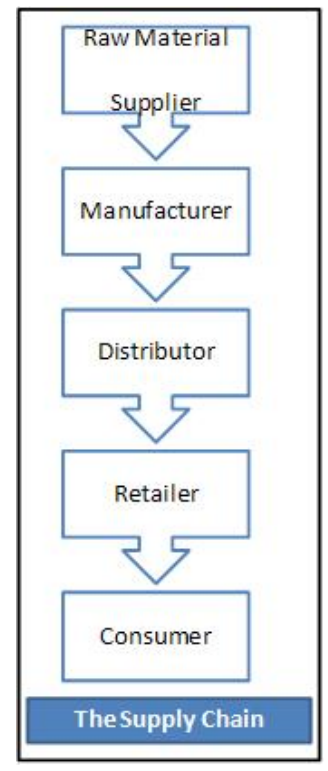

Figure 2 Supply Chain - Romney \& Steinbart.

As stated by Whitten, Bentley \& Dittman (2004), Supply Chain Management is a software application that would optimize the process of sourcing, ordering and delivery of goods to the customers. Balou (2007) stated that Supply Chain Management is the integration of logistics functions, material management, purchasing and transportation (see digram 3).

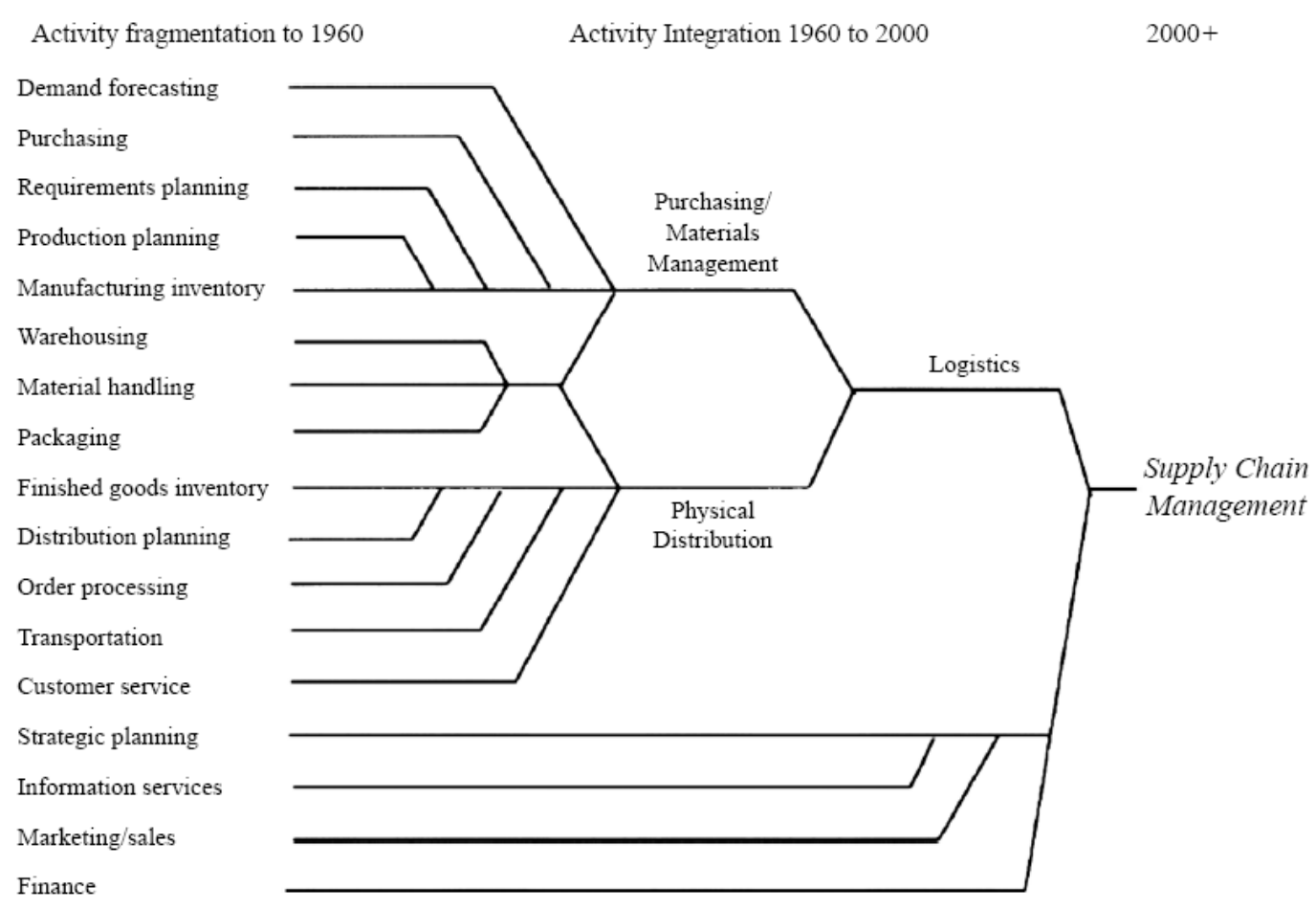

Figure 3 The Evolution of SCM 


\section{METHOD}

In this paper, the writer will summarize a strategy that would cover for the company's strategic needs and to measure the KPI of the company. To help in determining The KPI, the Balanced Scorecard tools are used to determine the KPI which will be derived from the Business Objectives of the company. The whole activity can be seen in the following “Bainstorming Diagram”.

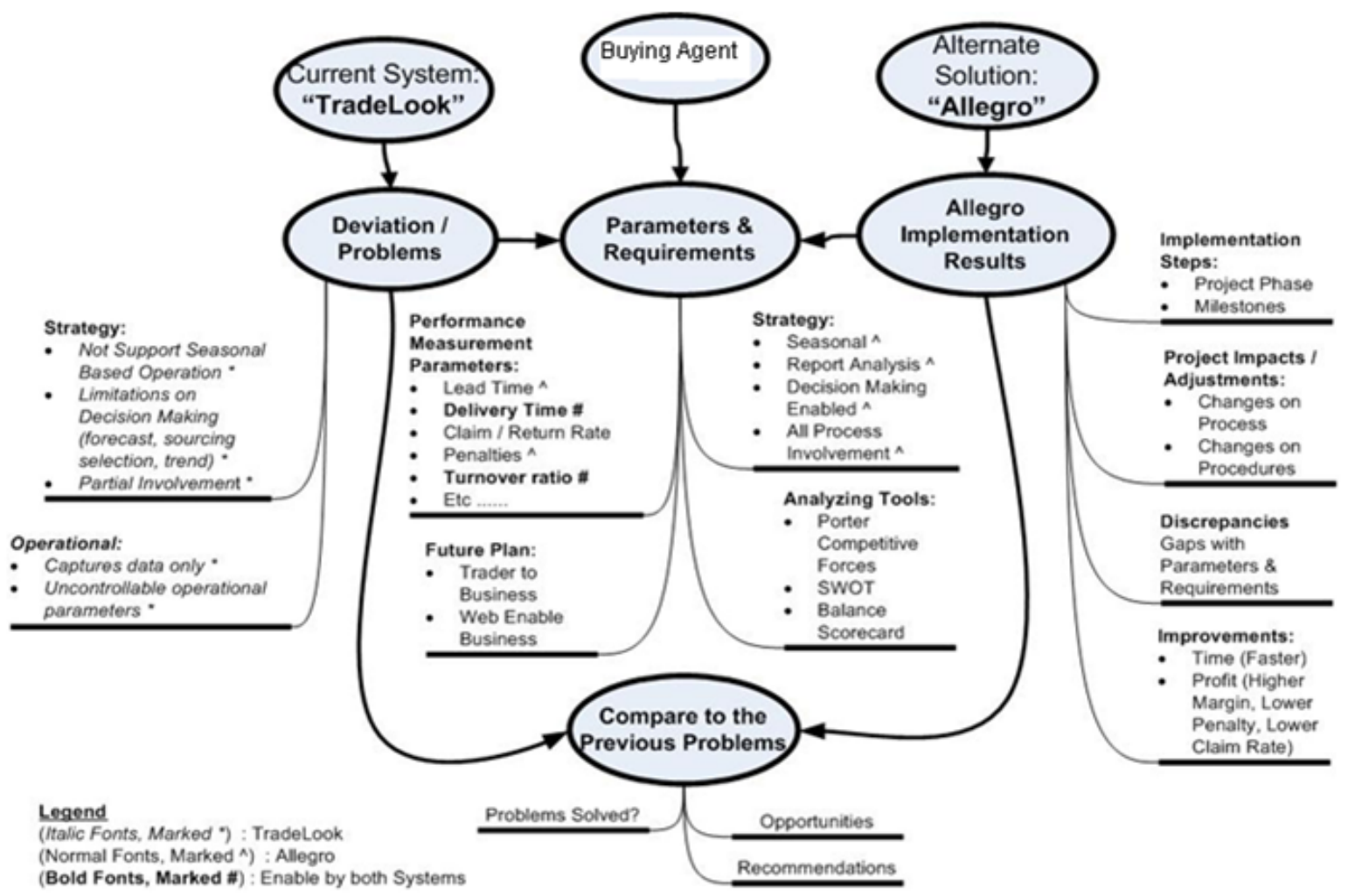

Figure 4 Brainstorming Diagram

\section{Data Collection}

The data is obtained from two sources, the main data is will be used for the research and the other source is the data that was obtained by interviewing the management of the company (buying agent). Data is obtaine by methods like (1) observation, this is done by observing the daily process of the company; (2) interview, interviewing the Management and the operational users, meaning all users involved in the overall process, the merchandise department, the quality assurance department and lastly the shipping department; (3) system generated data, some data are obtained directly from the software, especially the management reports such as delivery punctuality, lead time, claim rate, rejection rate and turnover report.

\section{Business Objectives}

The business objective will be used to derive the KPI of the company as well as the employee. The business objectives of the company are (1) revenue: increase reveue, can be obtained from the turnover report; (2) order control: to ensure that the orders are have minimum lead time, especially for 
repeat order, can be obtained from the Lead Time report; (3) delivery: to ensure the delivery punctuality of an order, can be be obtained from the delivery Performance report; (4) return from customer: to reduce claim rate (return) by able to choose the best supplier to handle the particular item; (5) return to supplier: to ensure the goods quality as per expected quality defined by the buyer; (6) source: sourcing for good supplier.

\section{The Business Process}

Buyers can meet directly with the merchandisers of buyers can place oders through their B2B system. I either case, the resulting is thuance of a Purchase Order. Once PO is confirmed, the orders must be followed up, making sure production of each part of an item is performed on time. Periodically at an agreed date, samples must be submitted. Once the goods is produced, the quality inspector must make sure that goods passed the inspection and ready to be sent. Shipping department then arrange to find appropriate ships (if by sea) or plane (if by air) to deliver the goods. The process can be seen in the following Figure 5 .

\section{Order Process}

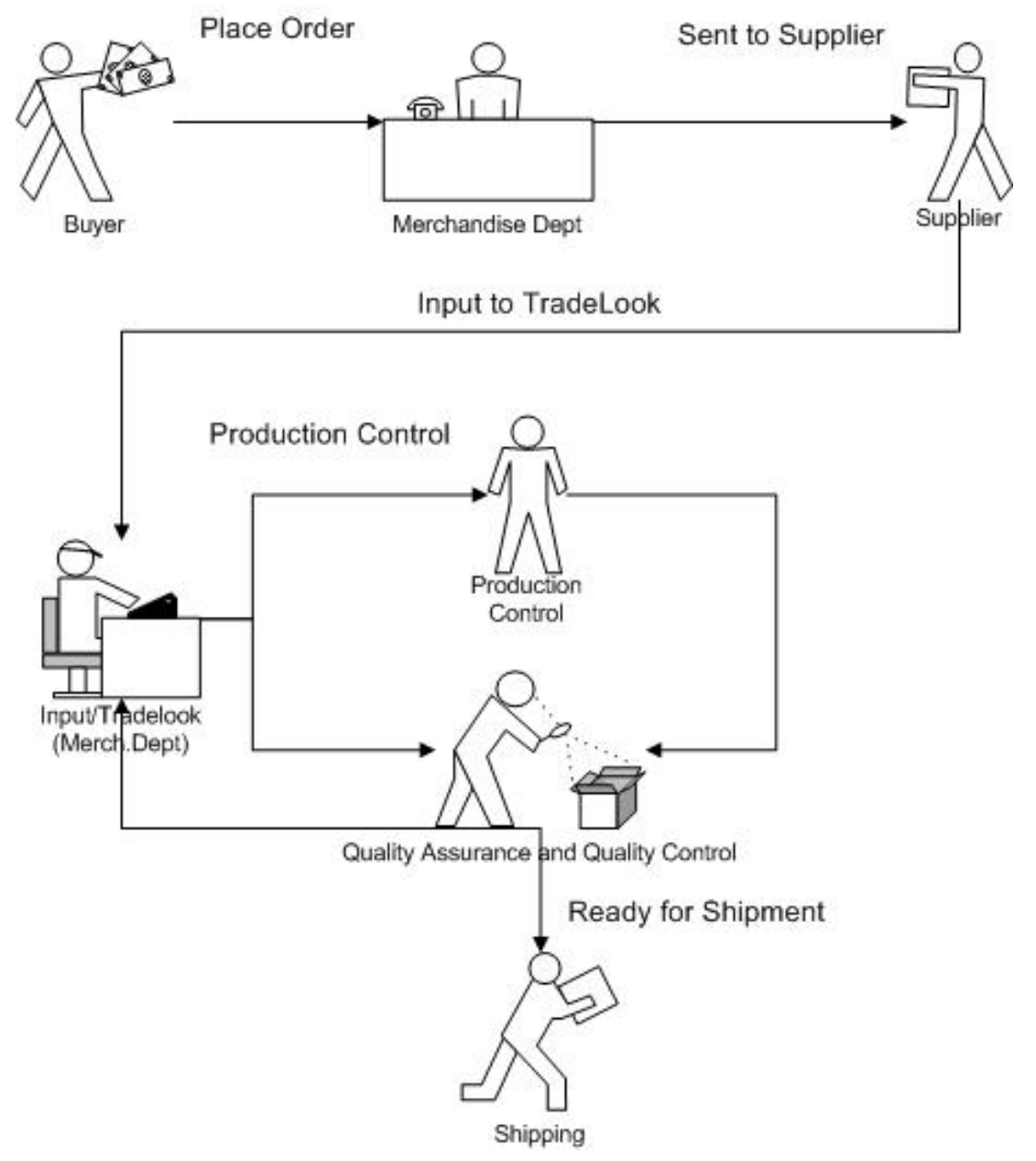

Diagram 5: Order Processing 


\section{Proposed Solution}

Allegro is only used to store the PO data, quality data and shipment data. From our observation, the software has another module which is Production Control, currently not used by the company.

The reports available from Allegro are divided into 4 main categories: merchandising, quality, shipping, and management reports. All reports can be printed sorted by season, per departemen, per Buyer dan per merchandising group. Inofrmation on suppliers are actually stored in detail however the system does not provide reports on this. In fact, the user must print this report and analyze manually then determine which the best supplier is. This matter can serve as our entry point, we can suggest that choosing the supplier can be done electronically by the system, as all information are actually available. This way, the decisin making does not need to be performed manually and henece it will improve the merchandiser's job.

\section{Allegro Implementation Evaluation}

Master data must be enetered manually. This is taken from all the available PO. The quality data can be partly obtained from the PO. Shipping data can be partly obtained from the quality data. Once data is ready, all reports can be printed. The writer concentrated on the management report as this is the key to improve the software and to improve the buying agent's performance.

\section{DISCUSSION}

\section{Result and Target}

Based on SWOT analysis, Porter's (1985) Competitive Forces dan business objectives of the Buying Agent, the implementation of Allegro can be used in order to support the business strategically. And since all reports are available, some can be derived the KPI of the company. The folloing reports have been used to do so.

\section{Financial Perspective}

Turnover target is to increase of $5 \%$ dari turnover from previous turnover.

\section{Internal Perspective} Order.

Transaction Volume Increment Repeat Order target is to increase of $10 \%$ volume Repeat

\section{Customer Perspective}

The customer perspective targets are devided into 4 parts, they are (1) penalty, will be applied if the company can not deliver goods punctually: targets in $0 \%$ (zero percent) penalty per order; (2) claim rate, claim atau return rate are the goods that are returned due to quality problem, this can be used to measure the performance of the quality inspectors and the company in general: targets in $0 \%$ (zero percent) per buyer; (3) delivery punctuality, this is the most important factor for the company. The company must ensure punctual deliver. In case of some problem whereby the supplier agree to ship the goods by air instead of by sea, then the delivery punctualiy will still be counted as punctual. The calculation is based on ETA date: target in 100\% punctual per Supplier; (4) lead time, is the time 
needed for the supplier to prepare for the goods after the receipt of the PO. For new items, it would take about 3 to 4 weeks, except for repeat order the expected lead time is 0 (Zero): targets in 3 weeks for new order and 0 untuk repeat order.

\section{Innovation \& Learning Perspective}

Innovation \& learning perspective consists of (1) supplier selection time, manually it would take the merchandise department at least 2 weeks to analyze and determine a supplier. With the help of Allegro, this figure can be reduced: target in 1 week to determine the best supplier; (2) system utilization, user involvement: targets in all departments should use allegro for the benefit of the company.

\section{Kpi Summary - Target}

By having KPI, it is expected the company can improve their overall performance. The delivery performance plays an important factor, as this will have an impact on the customer's satisfaction. For production control, Allegro has a module called Time Actiion Calendar (TAC). This module currently not used. It is highly recommended that the company will use this module as it will help in the production control and if production is on time, most likely delivery will be on time as well.

Tabel 1 Summary of target KPI Implementasi Allegro

\begin{tabular}{|c|c|}
\hline PERSPECTIVE - SELECTED KPI & TARGET \\
\hline \multicolumn{2}{|l|}{ FINANCIAL PERSPECTIVE } \\
\hline - $5 \%$ Up Comission than 2008 & $+5 \%$ \\
\hline \multicolumn{2}{|l|}{ CUSTOMER PERSPECTIVE } \\
\hline - $\quad$ Transaction Volume - Repeat Order & $+10 \%$ \\
\hline \multicolumn{2}{|l|}{ INTERNAL PERSPECTIVE } \\
\hline - Penalty & $0 \%$ per Order \\
\hline - $\quad$ Claim Rate & $0 \%$ per Order \\
\hline - $\quad$ Delivery Punctuality & $100 \%$ per Order \\
\hline - Lead Time & $\begin{array}{l}3 \text { Weeks (New Order); } \\
0 \text { Repeat Order }\end{array}$ \\
\hline \multicolumn{2}{|c|}{ INOVATION AND LEARNING PERSPECTIVE } \\
\hline - Supplier Selection Time & 2 Weeks \\
\hline - System Utilization - User Involvement & All Dept \\
\hline
\end{tabular}

\section{Strategy Map}

From the Key Performance Indicators, a summary of the strategic map can be formulized. See the following Figure 6. 


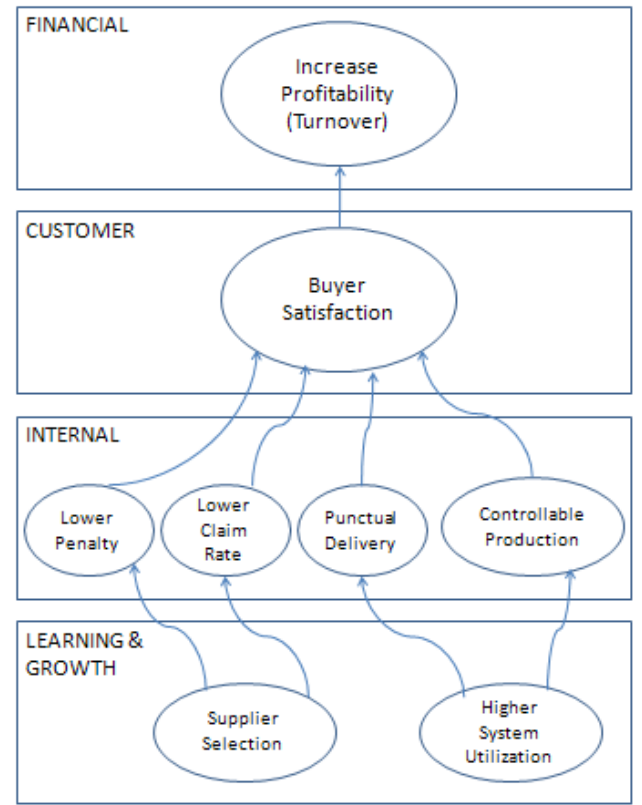

Diagram 6 Strategy Map

\section{Strategic Issues and Future Improvement}

\section{Analysis of Allegro Implementation}

Allegro actually can produce reports that is related to the KPI, unfortunately it inot being used. With the use of the system fully and preferable added the supplier decision module, Allegro can be utilized to support the company strategically and to measure the company's KPI. This way the overall performance of the company is improved. The following reports can be obtained from Allegro System:

Tabel 2 Allegro’s Capability as a support for SCM

\begin{tabular}{|c|c|c|c|c|c|}
\hline \multirow[t]{2}{*}{ NO } & \multirow[t]{2}{*}{ SCM Benefits } & \multirow{2}{*}{$\begin{array}{l}\text { Functions in } \\
\text { ALLEGRO }\end{array}$} & \multirow{2}{*}{$\begin{array}{c}\text { Availability of } \\
\text { Information } \\
\text { from } \\
\text { ALLEGRO }\end{array}$} & \multicolumn{2}{|c|}{ Potential Improvement } \\
\hline & & & & FORECAST & $\begin{array}{c}\text { SYSTEM } \\
\text { DECISION } \\
\text { (DSS) }\end{array}$ \\
\hline 1 & $\begin{array}{l}\text { Benefits : } \\
\text { - } \text { Better } \\
\text { nProduction } \\
\text { control and } \\
\text { quality control } \\
\text { - Help the } \\
\text { company } \\
\text { prepare } \\
\text { budget }\end{array}$ & $\begin{array}{l}\text { - } \text { Productivity } \\
\text { Statistics } \\
\text { - Turnover } \\
\text { Analysis per } \\
\text { season, per } \\
\text { year, per-office }\end{array}$ & $\begin{array}{lr}\text { - Using } & \text { Allegro } \\
\text { reports however } \\
\text { still involved } \\
\text { some manual } \\
\text { work }\end{array}$ & - & $\begin{array}{l}\text { Supplier } \\
\text { Selection }\end{array}$ \\
\hline \multirow[t]{2}{*}{2} & $\begin{array}{l}\text { Performance: } \\
\text { - Supplier's } \\
\text { performance }\end{array}$ & $\begin{array}{l}\text { - Delivery } \\
\text { performance } \\
\text { - Lead Time }\end{array}$ & $\begin{array}{l}\text { - Delivery } \\
\text { Performance } \\
\text { Report }\end{array}$ & - & $\begin{array}{l}\text { Supplier } \\
\text { Selection }\end{array}$ \\
\hline & $\begin{array}{l}\text { - Internal } \\
\text { performance }\end{array}$ & - Claim rate, & $\begin{array}{l}\text { - Productivity } \\
\text { Statistic Report }\end{array}$ & $\begin{array}{c}\text { Demand } \\
\text { Forecasting }\end{array}$ & $\begin{array}{l}\text { Supplier } \\
\text { Selection }\end{array}$ \\
\hline
\end{tabular}




\begin{tabular}{|c|c|c|c|c|c|}
\hline & \multirow[t]{3}{*}{ improvement } & \multirow[t]{3}{*}{$\begin{array}{l}\text { rejection rate } \\
\text { - Turnover }\end{array}$} & \multirow{2}{*}{$\begin{array}{l}\text { • Turnover report } \\
\text { • Claim Report }\end{array}$} & \multirow{2}{*}{$\begin{array}{c}\text { Demand } \\
\text { Forecasting } \\
-\end{array}$} & \multirow{3}{*}{$\begin{array}{c}- \\
\text { Supplier } \\
\text { Selection } \\
\text { Supplier } \\
\text { Selection }\end{array}$} \\
\hline & & & & & \\
\hline & & & $\begin{array}{l}\text { - Rejection Rate } \\
\text { Report }\end{array}$ & - & \\
\hline 3 & $\begin{array}{l}\text { Improement in } \\
\text { supplier and buyer } \\
\text { integration } \\
\text { - Reduce same } \\
\text { and cost } \\
\text { - Product } \\
\text { monitoring }\end{array}$ & - Sampling & $\begin{array}{l}\text { - Time and } \\
\text { Action } \\
\text { Calendar (*) }\end{array}$ & - & $\begin{array}{l}\text { Supplier } \\
\text { Selection }\end{array}$ \\
\hline \multirow[t]{3}{*}{4} & \multirow{3}{*}{$\begin{array}{l}\text { Supplier /Decision } \\
\text { for Sourcing: } \\
\text { - } \quad \text { Better } \\
\text { customer } \\
\text { satisfaction }\end{array}$} & \multirow{3}{*}{$\begin{array}{l}\text { - Delivery } \\
\text { performance } \\
\text { - Lead Time } \\
\text { - Claim rate, } \\
\text { rejection rate }\end{array}$} & $\begin{array}{l}\text { - Production } \\
\text { Status Report }\end{array}$ & - & $\begin{array}{l}\text { Supplier } \\
\text { Selection }\end{array}$ \\
\hline & & & $\begin{array}{l}\text { - Delivery } \\
\text { Performance } \\
\text { Report }\end{array}$ & - & $\begin{array}{l}\text { Supplier } \\
\text { Selection }\end{array}$ \\
\hline & & & $\begin{array}{cc}\text { - Order } & \text { Status } \\
\text { Report } & \\
\end{array}$ & - & - \\
\hline \multirow[t]{5}{*}{5} & \multirow{5}{*}{$\begin{array}{l}\text { Minimize Return / } \\
\text { Re-Work: } \\
\text { - Low Claim } \\
\text { Rate } \\
\text { - Reduce cost } \\
\text { per order }\end{array}$} & \multirow{5}{*}{$\begin{array}{l}\text { - Sampling } \\
\text { Control } \\
\text { - Production } \\
\text { Control } \\
\text { - Quality } \\
\text { Assurance } \\
\text { - Goods } \\
\text { Inspections }\end{array}$} & $\begin{array}{l}\text { - Time and } \\
\text { Action } \\
\text { Calendar }\left(^{*}\right) \\
\end{array}$ & - & - \\
\hline & & & $\bullet$ & & \\
\hline & & & $\bullet$ & & \\
\hline & & & $\begin{array}{l}\text { - Production } \\
\text { status }\end{array}$ & - & - \\
\hline & & & $\begin{array}{l}\text { - Inspection } \\
\text { Report }\end{array}$ & - & - \\
\hline \multirow[t]{2}{*}{6} & \multirow{2}{*}{$\begin{array}{l}\text { Order } \\
\text { Forecasting: } \\
\text { - } \quad \text { Product } \\
\text { offerinf }\end{array}$} & \multirow{2}{*}{$\begin{array}{l}\text { - Turnover } \\
\text { Comparison per } \\
\text { season, per year } \\
\text { - Best selling } \\
\text { item }\end{array}$} & $\begin{array}{l}\text { - Turnover } \\
\text { Analysis Report }\end{array}$ & $\begin{array}{c}\text { Demand } \\
\text { Forecasting }\end{array}$ & - \\
\hline & & & $\begin{array}{l}\text { - Top } \\
\text { Item }\end{array}$ & $\begin{array}{c}\text { Demand } \\
\text { Forecasting }\end{array}$ & - \\
\hline
\end{tabular}

Keterangan: $\left(^{*}\right)$ Not yet used

\section{CONCLUSION}

Allegro has all the information needed by the customer, however, some modules are not used. This module in fact ohas the potential to benefit the company as it can serve the company strategically and the company can therefore improe their performance. Iwith the availability of the Balance Score Card and KPI, the company can improve their performance and also the staff's performance. If all the modules are used as per our recommendation, it can be seen that improement has been done on the shown Figure 7 below. 


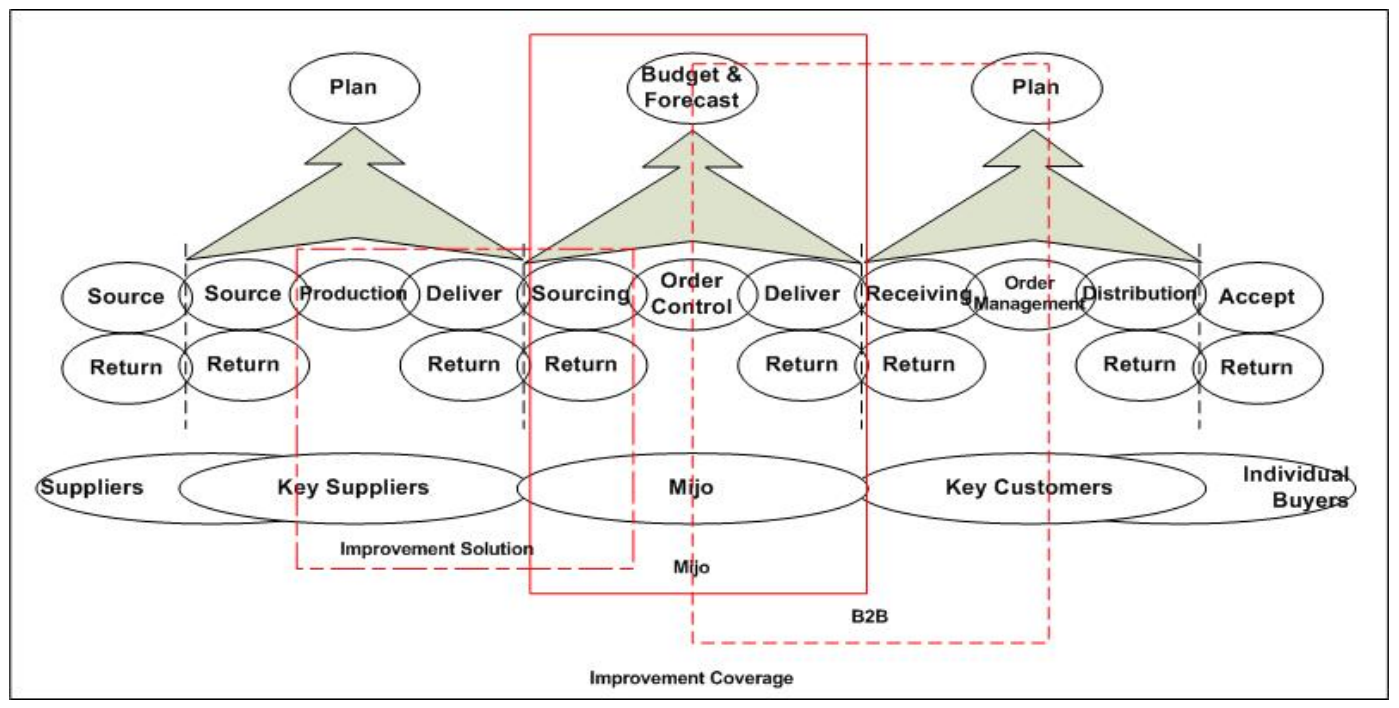

Figure 7 Improvement Coverage

\section{BIBLIOGRAPHY}

Ballou, R.H. (2007). The evolution and future of logistics and supply chain management, Weatherhead School of Management. European Business Review Vol. 19 No. 4, pp. 332-348.

Chaffey, D., \& Wood, S. (2005). Business Information Management: Improving Performance Using Information Systems. Essex: Prentice-Hall.

Porter, M. E. (1985). Competitive Advantage: Creating and Sustaining Superior Performance. New York: Free Press.

Romney, M. B., \& Steinbart, P. J. (2006). Accounting Information Systems (10th ed.). Upper Saddle River, NJ: Prentice Hall.

Whitten, J. L., Bentley, L. D., \& Dittman, K. C. (2004). System Analysis \& Design Methods (6th ed.). New York: McGraw-Hill. 